\title{
Zebrafish TRPA1 Channels Are Required for Chemosensation But Not for Thermosensation or Mechanosensory Hair Cell Function
}

\author{
David A. Prober, ${ }^{1}$ Steven Zimmerman, ${ }^{1}$ Benjamin R. Myers, ${ }^{2 \star}$ Brian M. McDermott Jr, ${ }^{3 \star}$ Seok-Hyung Kim, ${ }^{4 *}$ \\ Sophie Caron, ${ }^{1}$ Jason Rihel, ${ }^{1}$ Lilianna Solnica-Krezel, ${ }^{4}$ David Julius, ${ }^{2}$ A. J. Hudspeth, ${ }^{5}$ and Alexander F. Schier ${ }^{1}$ \\ ${ }^{1}$ Department of Molecular and Cellular Biology, Center for Brain Science, Harvard Stem Cell Institute and Broad Institute, Harvard University, Cambridge, \\ Massachusetts 02138, 2Department of Physiology, University of California, San Francisco, San Francisco, California 94143, ${ }^{3}$ Department of Otolaryngology- \\ Head and Neck Surgery, Case Western Reserve University School of Medicine, Cleveland, Ohio 44106, ${ }^{4}$ Department of Biological Sciences, Vanderbilt \\ University, Nashville, Tennessee 37235, and ${ }^{5}$ Howard Hughes Medical Institute and Laboratory of Sensory Neuroscience, The Rockefeller University, New \\ York, New York 10065
}

Transient receptor potential (TRP) ion channels have been implicated in detecting chemical, thermal, and mechanical stimuli in organisms ranging from mammals to Caenorhabditis elegans. It is well established that TRPA1 detects and mediates behavioral responses to chemical irritants. However, the role of TRPA1 in detecting thermal and mechanical stimuli is controversial. To further clarify the functions of TRPA1 channels in vertebrates, we analyzed their roles in zebrafish. The two zebrafish TRPA1 paralogs are expressed in sensory neurons and are activated by several chemical irritants in vitro. High-throughput behavioral analyses of trpa1a and trpa1b mutant larvae indicate that TRPA1b is necessary for behavioral responses to these chemical irritants. However, TRPA1 paralogs are not required for behavioral responses to temperature changes or for mechanosensory hair cell function in the inner ear or lateral line. These results support a role for zebrafish TRPA1 in chemical but not thermal or mechanical sensing, and establish a high-throughput system to identify genes and small molecules that modulate chemosensation, thermosensation, and mechanosensation.

Key words: nociception; temperature; mechanosensory; chemosensory; behavior; hair cell

\section{Introduction}

The zebrafish has emerged as a powerful system to study the genetic and neural circuits that regulate behavior (Granato et al., 1996; Nicolson et al., 1998; Barth et al., 2005; Muto et al., 2005; Prober et al., 2006; Bhatt et al., 2007; Burgess and Granato, 2007; McLean et al., 2007; McLean and Fetcho, 2008; Orger et al., 2008). Zebrafish larvae detect a variety of thermal, chemical, and

\footnotetext{
Received June 16, 2008; revised Aug. 22, 2008; accepted Aug. 24, 2008

This work was supported by National Institutes of Health (NIH) Grants DC00241 (A.J.H.), NS055799 (D.J.), and NS049319 (A.F.S.); the Zebrafish Vanderbilt Initiative Academic Venture Capital Fund (L.S.-K.); the University Hospitals Case Medical Center - Center for Clinical Research and Technology (B.M.M.); and the Case Research Institute Vision Fund (B.M.M.). D.A.P. was supported by a fellowship from the Helen Hay Whitney Foundation and an NIH Pathway to Independence award. B.R.M. is a Predoctoral Fellow of the American Heart Association. B.M.M. is supported by a Basil O'Connor Starter Scholar Research Award from the March of Dimes. J.R. is a Bristol-Myers Squibb Life Sciences Research Foundation Fellow. A.J.H. is an Investigator of the Howard Hughes Medical Institute. We thank Drs. Cuppen, de Bruin, and Plasterk (Hubrecht laboratory) and Drs. Kettleborough and Stemple (Welcome Trust Sanger Institute) for providing the zebrafish trpa 1a knock-out mutant (ZF-MODELS Integrated Project; contract number LSHG-CT-2003-503496; funded by the European Commission). We thank B. Fabella for providing the software for recording microphonic potentials, M. Vologodskaia and C. Fernando for genotyping larvae used in microphonic potential recordings and FM1-43 experiments, M. West for performing FM1-43 injections, and David Schoppik and lan Woods for comments on this manuscript.

*B.R.M., B.M.M., and S.-H.K. contributed equally to this work.

Correspondence should be addressed to either David A. Prober or Alexander F. Schier, Department of Molecular and Cellular Biology, Center for Brain Science, Harvard University, 16 Divinity Avenue, Cambridge, MA 02138. E-mail: prober@fas.harvard.edu or schier@mcb.harvard.edu.

D0I:10.1523/JNEUROSCI.2740-08.2008

Copyright $\odot 2008$ Society for Neuroscience $\quad$ 0270-6474/08/2810102-09\$15.00/0
}

mechanical stimuli through trigeminal and Rohon-Beard sensory neurons, whose cutaneous peripheral axons innervate the head and trunk, respectively (Metcalfe et al., 1990; Sagasti et al., 2005). These stimuli are also detected internally by the epibranchial sensory ganglia, which innervate visceral organs such as the gut and intestine (Olsson et al., 2008). Although the development of these sensory systems has been well characterized in zebrafish (Raible and Ungos, 2006; Nechiporuk et al., 2007), little is known about the molecules responsible for detecting specific stimuli. The optical transparency of zebrafish larvae and the amenability of zebrafish to large-scale genetic and pharmacologic screens (Driever et al., 1996; Granato et al., 1996; Haffter et al., 1996; Peterson et al., 2000; North et al., 2007; Sachidanandan et al., 2008) make it an excellent system to identify the genes and neurons that regulate behavior. Furthermore, the robust behaviors exhibited by zebrafish larvae (Muto et al., 2005; Prober et al., 2006; Burgess and Granato, 2007; McLean and Fetcho, 2008; Orger et al., 2008) make them well suited for studying the roles of candidate molecules in regulating these behaviors.

Studies in mammals, Drosophila melanogaster and Caenorhabditis elegans identified transient receptor potential (TRP) ion channels as responsible for detecting a range of thermal, chemical, and mechanical stimuli (Bandell et al., 2007; Caterina, 2007; Christensen and Corey, 2007; Montell and Caterina, 2007). A particularly intriguing TRP channel is TRPA1, which has been 
implicated in detecting noxious chemicals in mammals and Drosophila (Bandell et al., 2004; Jordt et al., 2004; Bautista et al., 2005; Macpherson et al., 2005, 2007; Al-Anzi et al., 2006; Bautista et al., 2006; Kwan et al., 2006; McNamara et al., 2007; Trevisani et al., 2007), in mediating thermotaxis in Drosophila (Rosenzweig et al., 2005; Hamada et al., 2008; Kwon et al., 2008), and in mechanotransduction in mammals and C. elegans (Kwan et al., 2006; Kindt et al., 2007). Some reports (Story et al., 2003; Bandell et al., 2004; Kwan et al., 2006; Klionsky et al., 2007; Sawada et al., 2007; Fajardo et al., 2008), but not others (Jordt et al., 2004; Bautista et al., 2006), also implicated TRPA1 in detecting noxious cold, although subsequent studies suggested that this was an indirect result of increased intracellular $\mathrm{Ca}^{2+}$ concentration (Doerner et al., 2007; Zurborg et al., 2007). A previous report using short interfering RNA (siRNA) in mammals and morpholino antisense oligonucleotides in zebrafish suggested that TRPA1 forms part of the hair cell mechanotransduction channel that is required for inner ear and lateral line hair cell function (Corey et al., 2004). However, subsequent work found that inner ear hair cell function is normal in TRPA1 knock-out mice (Bautista et al., 2006; Kwan et al., 2006). To clarify the function of TRPA1 channels in vertebrates, we generated null mutations in both zebrafish TRPA1 paralogs and assessed their contribution to behavioral responses to chemical, thermal, and mechanical stimuli.

\section{Materials and Methods}

Isolation of zebrafish trpala and trpalb cDNAs

Full-length trpala and trpalb cDNAs were amplified by performing reverse transcription-PCR with Superscript II (Invitrogen) using primers based on sequence from $5^{\prime}$ rapid amplification of cDNA ends (RACE; First Choice RLM-RACE; Ambion) and Ensembl exon prediction. The cDNA sequences have been deposited in GenBank under accession numbers EU826643 (trpa1a) and EU826642 (trpa1b).

\section{In situ hybridization}

Single in situ hybridizations were performed using standard protocols and developed using nitroblue-tetrazolium chloride and 5-bromo-4chloro-indolyl-phosphate (Roche). Double-fluorescence in situ hybridizations were performed using digoxigenin- and 2,4-dinitrophenol (DNP)-labeled riboprobes and the TSA Plus DNP System (PerkinElmer).

\section{In vitro studies of zebrafish TRPA1 function}

Mammalian cell culture and calcium imaging. HEK293T cells were maintained in standard DME H-21 medium supplemented with $10 \%$ fetal bovine serum. Transfection was achieved using Lipofectamine 2000 (Invitrogen) according to the manufacturer's instructions $\left(250 \mathrm{ng} / \mathrm{cm}^{2}\right.$ of channel cDNA.) The following day, cells were plated onto polyornithinecoated eight-well chamber slides, washed with Ringer's solution (in mм: $155 \mathrm{NaCl}, 4.5 \mathrm{KCl}, 2 \mathrm{CaCl}_{2}, 1 \mathrm{MgCl}_{2}, 10$ D-glucose, and 5 HEPES-Na, $\mathrm{pH}$ 7.4), and loaded with $10 \mu \mathrm{M}$ fura-2 $\mathrm{AM}+0.02 \%$ pluronic acid. Mustard oil, diallyl disulfide (DADS), and cinnamaldehyde were dissolved in DMSO, and 4-hydroxynonenal (4-HNE) was dissolved in ethanol. All drugs were diluted into Ringer's solution immediately before experiments.

Xenopus oocyte culture and electrophysiology. Surgically extracted oocytes from Xenopus laevis frogs (Nasco) were maintained in standard ND-96 medium supplemented with antibiotics, injected with 1-10 ng of in vitro transcribed cRNA (mMessage machine; Ambion), and analyzed 3-5 d later. For two-electrode voltage clamp, the bath contained the following (in mM): $120 \mathrm{CsCl}, 10 \mathrm{HEPES}, 2 \mathrm{MgCl}_{2}-6 \mathrm{H}_{2} \mathrm{O}$, and 1 EGTA, $\mathrm{pH}$ 7.4. Electrodes were filled with $3 \mathrm{M} \mathrm{KCl}$ and had resistances of $0.2-2$ $\mathrm{M} \Omega$. Two-electrode voltage clamp was performed with a GeneClamp 500 amplifier (Molecular Devices) using a $320 \mathrm{~ms}$ voltage ramp from -100 $\mathrm{mV}$ to $+80 \mathrm{mV}$ delivered once per second. Mustard oil was diluted into recording solution immediately before experiments.
Generation of trpala and trpalb mutant zebrafish

Targeted induced local lesions in genomes (TILLING) was used to generate trpa $1 a$ and trpa $1 b$ null mutants, as described previously (Wienholds et al., 2002).

\section{Behavioral analysis}

Larvae were raised on a $14 / 10 \mathrm{~h}$ light/dark cycle at $28.5^{\circ} \mathrm{C}$. On the third day of development, single larvae were placed in each of 80 wells of a 96-well plate (290-8121-010; Evergreen Scientific). The plate lacks a base, and a $300 \mu \mathrm{m}$ nylon mesh (M300; Aquatic Ecosystems) was glued to the base of the plate with Instant Krazy Glue (Elmers). The plate was soaked in $2 \mathrm{~L}$ of water for $48 \mathrm{~h}$ after the glue cured. The plate was placed in a chamber filled with circulating water pumped from a $28.5^{\circ} \mathrm{C}$ water bath (supplemental Fig. 3B, available at www.jneurosci.org as supplemental material) in a custom-modified Zebrabox (ViewPoint Life Sciences). Larvae were maintained in the dark for $24 \mathrm{~h}$ before behavior analysis and throughout the experiment. The locomotor activity of each larva was monitored by an automated video tracking system (supplemental Fig. $3 A$, available at www.jneurosci.org as supplemental material) (Videotrack; ViewPoint Life Sciences) and analyzed as previously described (Prober et al., 2006). Larvae were exposed to heated or cooled water by switching the circulating water flow to water baths containing water heated using a hotplate (11-600-49SH; Fisher Scientific) or cooled by a secondary reservoir containing ice. The temperature in the Zebrabox chamber was monitored using a YSI Precision Thermometer (model 4600 ) and cuvette probe (model 451; YSI Temperature). For tapping assays, an intermittent-duty push-type solenoid (28P-I-12D; Guardian Electric) was mounted outside the water-filled chamber that contains the 96-well plate. The contacts of the solenoid were wired to a switch that controlled a fixed current provided by a $12 \mathrm{~V} \mathrm{DC}, 1000 \mathrm{~mA}, \mathrm{AC} / \mathrm{DC}$ transformer. Taps were administered by switching on the $12 \mathrm{~V}$ DC supply. In control experiments, taps did not cause movement artifacts in wells that lacked larvae. For chemical experiments, the circulating water flow was switched to reservoirs containing 1\% DMSO (MX1458-6; EMD Chemicals), allyl isothiocyanate (mustard oil; 377430; Sigma-Aldrich; diluted to $100 \mu \mathrm{M}$ in 1\% DMSO), cinnamon oil (C7267; SigmaAldrich; diluted to $500 \mu \mathrm{M}$ in 1\% DMSO), DADS (32621; Sigma-Aldrich; diluted to $200 \mu \mathrm{M}$ in 1\% DMSO) or acrolein (01679; Sigma-Aldrich; diluted to $300 \mu \mathrm{M}$ in water). For 4-HNE (393204; EMD Chemicals) experiments, day 3 larvae were gently pipetted into a solution containing either water or 4-HNE diluted to $200 \mu \mathrm{M}$ in water. Behavioral responses were recorded using a Canon digital video camcorder (ZR80).

\section{Analysis of hair cell function}

Microphonic potentials were recorded from the otocysts of 7-d-old larvae using established techniques (Kappler et al., 2004; Starr et al., 2004). Each larva was immobilized on its side against the coverglass bottom of an experimental chamber with $1.4 \%$ low-melting-point agarose in oxygenated solution containing $120 \mathrm{~mm} \mathrm{NaCl}$ and $650 \mathrm{~mm}$ of the anesthetic 3 -aminobenzoic acid ethyl ester methanesulfonate (MESAB). A piezoelectric stimulator (PZL-015-11; Burleigh) driven by a high-voltage amplifier (PZ-150 M; Burleigh) provided five-cycle bursts of $200 \mathrm{~Hz}, \pm 3$ $\mu \mathrm{m}$ sinusoidal stimuli, which were delivered axially to the front of the animal's head by a glass probe attached to the stimulator. A glass microelectrode containing $3 \mathrm{M} \mathrm{KCl}$, advanced into the otocyst by a micromanipulator, recorded microphonic potentials with respect to a ground electrode in the bath. The signals were amplified (Axoclamp-2A; Molecular Devices), low-pass filtered at $4 \mathrm{kHz}$, digitally sampled every $50 \mathrm{~ms}$, and averaged with software written in LabVIEW (National Instruments).

Labeling of inner ear hair cells was performed by pressure injecting (Corey et al., 2004) $50 \mathrm{nl}$ of FM1-43 dye (Invitrogen) at a concentration of $50 \mu \mathrm{M}$ into the otocyst of larvae that were anesthetized with $650 \mathrm{~mm}$ MESAB. Imaging was performed between 5 and $10 \mathrm{~min}$ after injection on a DM IRE2 inverted confocal laser-scanning microscope (Leica Microsystems). Labeling of lateral line hair cells was accomplished by incubating larvae in $7 \mu \mathrm{M}$ FM1-43 dye for $5 \mathrm{~min}$. Subsequently, animals were washed in fish water and anesthetized with $650 \mathrm{~mm}$ MESAB. Animals were imaged using an MZFLIII fluorescence stereomicroscope (Leica Microsystems). To ablate lateral line hair cells before FM1-43 treatment, 

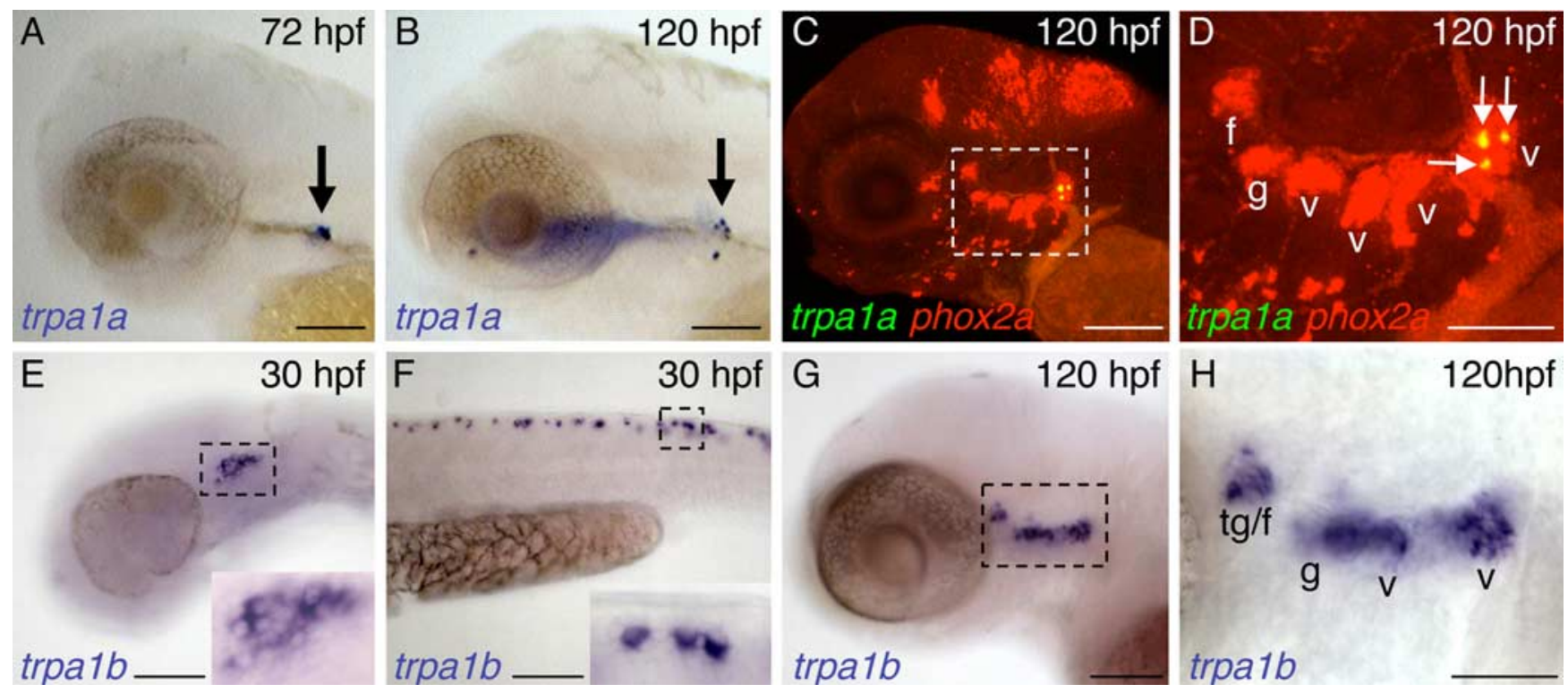

Figure 1. Zebrafish trpa $1 a$ and trpa $1 b \mathrm{mRNA}$ expression patterns. $\boldsymbol{A}, \boldsymbol{B}$, trpa $1 a \mathrm{mRNA}$ is expressed in one or two neurons at $72 \mathrm{hpf}(\boldsymbol{A}$, arrow) and four or five neurons at $120 \mathrm{hpf}(\boldsymbol{B}$, arrow). $\boldsymbol{C}, \boldsymbol{D}$, Double-fluorescence in situ hybridization with phox2a (red), which labels epibranchial sensory ganglia, shows that trpa 1a expression is restricted to the most posterior vagal sensory ganglion (yellow, arrows). The boxed region in ( is shown at higher magnification in $\boldsymbol{D} . \boldsymbol{E}, \boldsymbol{F}$, trpa $1 b$ is expressed in a subset of trigeminal ( $\boldsymbol{E}$, boxed region enlarged in inset) and Rohon-Beard $(\boldsymbol{F}$, boxed region enlarged in inset) sensory neurons at $30 \mathrm{hpf} . \mathbf{G}, \boldsymbol{H}, \mathrm{By} 120 \mathrm{hpf}$, trpa $\mathbf{b} \boldsymbol{b}$ is expressed in a subset of neurons in all epibranchial sensory ganglia. The boxed region in $\boldsymbol{G}$ is shown at higher magnification in $\boldsymbol{H}$. f, Facial ganglion; g, glossopharyngeal ganglion; t, trigeminal ganglion; $\boldsymbol{V}$, vagal ganglion. Scale bars: $\boldsymbol{A}-\boldsymbol{C}, \boldsymbol{E}-\mathbf{G}, 100 \mu \mathrm{m} ; \boldsymbol{D}, \boldsymbol{H}, 50 \mu \mathrm{m}$.

larvae were incubated in $100 \mu \mathrm{M}$ neomycin (Santos et al., 2006) for 20 min and allowed to recover for $3 \mathrm{~h}$. For quantitation of FM1-43 dye uptake into hair cells of ear sensory patches and neuromasts, the pixel fluorescence intensity was determined for each sensory organ using Photoshop (Adobe Systems).

\section{Results}

\section{Zebrafish TRPA1 paralogs are expressed in sensory neurons}

In agreement with a previous report (Corey et al., 2004), we identified two zebrafish orthologs of mammalian TRPA1, designated TRPAla and TRPA1b (supplemental Fig. 1, available at www.jneurosci.org as supplemental material). These two genes are likely paralogs generated by a teleost-specific whole-genome duplication (Postlethwait, 2007). Using in situ hybridization, we found that trpala is exclusively expressed in the most posterior vagal sensory ganglion (Fig. $1 C, D)$. trpala expression is first detected in one or two neurons at $72 \mathrm{~h}$ postfertilization (hpf) (Fig. $1 A$ ) and expands to four or five neurons by $120 \mathrm{hpf}($ Fig. $1 \mathrm{~B})$. In contrast, trpa $1 b$ is expressed as early as $30 \mathrm{hpf}$ in a subset of trigeminal and Rohon-Beard sensory neurons (Fig. 1E,F). By $120 \mathrm{hpf}$, trpalb expression expands to include subsets of neurons in all cranial sensory ganglia (Fig. $1 G, H$ ). We did not observe expression of either TRPA1 paralog in ear or neuromast hair cells (data not shown). Because the most posterior vagal sensory ganglion innervates visceral organs such as the gut and intestine (Olsson et al., 2008), whereas the trigeminal and Rohon-Beard neurons innervate the skin (Metcalfe et al., 1990; Sagasti et al., 2005), TRPA $1 b$ likely detects both internal and external stimuli, whereas TRPAla likely only detects internal stimuli.

\section{Zebrafish TRPA1 paralogs are activated by chemical irritants in vitro}

Mammalian and Drosophila TRPA1 orthologs are activated by the pain-inducing natural product allyl isothiocyanate, commonly known as mustard oil (Bandell et al., 2004; Jordt et al., 2004; Bautista et al., 2005; Al-Anzi et al., 2006). To test whether the zebrafish TRPA1 paralogs are activated by mustard oil, we transfected HEK293T cells with plasmids that drive expression of either TRPA1a or TRPA1b. In contrast to cells transfected with vector alone, cells expressing TRPAla or TRPA1b showed robust increases in $\mathrm{Ca}^{2+}$ concentration in the presence of mustard oil (Fig. 2A). Similarly, mustard oil induced strong inward current in Xenopus oocytes expressing zebrafish TRPAla or TRPAlb (Fig. $2 B$ ). This response was reduced by coapplication of ruthenium red (Fig. $2 B$ ), which inhibits mammalian TRPA1 function. These results establish that both zebrafish TRPA1 paralogs can be activated by mustard oil.

Mammalian TRPA1 is activated by several other plant-derived natural products that elicit pain, including cinnamaldehyde (cinnamon oil) and DADS, the pungent components in cinnamon and garlic, respectively (Bandell et al., 2004; Bautista et al., 2005; Macpherson et al., 2005). Mammalian TRPA1 is also activated by environmental irritants such as acrolein (Bautista et al., 2006), the toxic component in tear gas and vehicle exhaust, and by 4-HNE (Macpherson et al., 2007; Trevisani et al., 2007), an endogenous compound that is produced in response to tissue injury, inflammation, and oxidative stress. Each of these compounds increased $\mathrm{Ca}^{2+}$ concentration in HEK293T cells expressing zebrafish TRPA1a or TRPA1b (supplemental Fig. 2, available at www.jneurosci.org as supplemental material). We therefore conclude that both zebrafish TRPA1 paralogs can be activated by a range of chemical irritants.

\section{Zebrafish TRPA1 paralogs are required for behavioral responses to chemical irritants}

Because the zebrafish TRPA1 paralogs are expressed in sensory neurons and are activated by chemical irritants in vitro, and because these irritants elicit TRPA1-dependent nociceptive behavioral responses in mice (Bautista et al., 2006; Kwan et al., 2006), we hypothesized that these irritants would elicit a similar response in zebrafish larvae. To test this hypothesis, we used an automated video tracking system to monitor the locomotor activity of large numbers of zebrafish larvae (supplemental Fig. 3, 
A
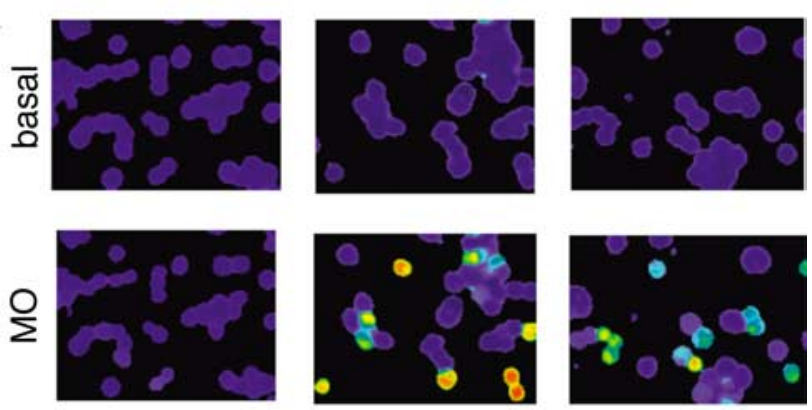

vector

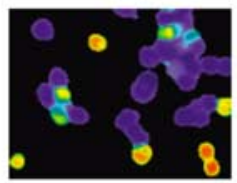

TRPA1a

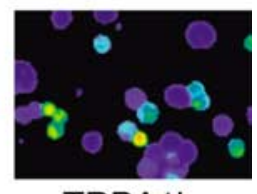

TRPA1b

B

water-injected mustard oil, $100 \mu \mathrm{M}$

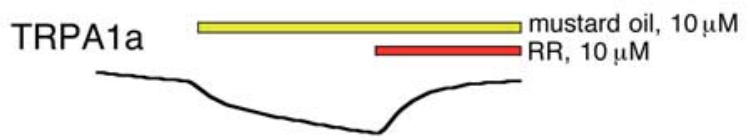

TRPA1b
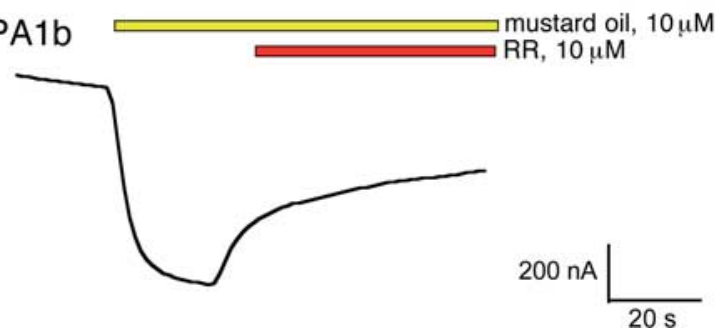

Figure 2. Zebrafish TRPA1 channels respond directly to mustard oil. $\boldsymbol{A}$, Ratiometric fura-2 $\mathrm{Ca}^{2+}$ images of HEK293T cells transfected with zebrafish TRPA1a or TRPA1b before or after stimulation with $100 \mu \mathrm{m}$ mustard oil (M0). B, Two-electrode voltage clamp recordings from Xenopus oocytes expressing zebrafish TRPA1a or TRPA1 $b$ and challenged at the indicated times with MO. The holding potential was $-60 \mathrm{mV}$. Ruthenium red (RR) completely blocked the M0-evoked responses for TRPA1a and partially blocked the responses for TRPA1b. Waterinjected oocytes served as a negative control.

available at www.jneurosci.org as supplemental material) (Prober et al., 2006). Individual larvae were placed into 80 wells of a 96-well plate. The plate was immersed in a recirculating water bath, and a fine mesh was used as the base of the plate, thus exposing the larvae to the water. This system allowed us to expose the larvae to different stimuli by switching between different water reservoirs.

We found that on the fourth day of development, zebrafish larvae maintained in the dark exhibit very little spontaneous locomotor activity (Fig. 3A). Similarly, exposure to 1\% DMSO had no effect on locomotor activity (Fig. $3 A, D$ ). In contrast, exposure to $100 \mu \mathrm{M}$ mustard oil in $1 \%$ DMSO elicited a robust increase in locomotor activity, consistent with an escape response from a noxious chemical (Fig. $3 A, D$ ). Similar responses were observed after exposure to cinnamon oil, DADS, acrolein (supplemental Fig. 4, available at www.jneurosci.org as supplemental material), and 4-HNE (supplemental Movie 1, available at www. jneurosci.org as supplemental material). Thus, as in mammals, these chemical irritants are noxious stimuli for zebrafish larvae.

To test whether the zebrafish TRPA1 paralogs are required for this behavioral response, we used a method known as TILLING to generate mutations in both genes (Wienholds et al., 2002). We generated trpala mutant fish in which an A-to-T transversion introduced a stop codon at amino acid $142\left(\operatorname{trpa1} a^{\text {hu2163 }}\right.$ ) (supplemental Fig. $1 A$, available at www.jneurosci.org as supplemental material). The protein encoded by this mutant gene lacks most ankyrin domains and all transmembrane domains, and should therefore lack all function. In situ hybridization revealed significantly reduced levels of trpa1a mRNA in homozygous mutants (data not shown), likely because of nonsense-mediated mRNA decay (Isken and Maquat, 2007). We also generated trpalb mutant fish in which an A-to-T transversion deletes the splicing acceptor site for exon $11\left(\operatorname{trpa} 1 b^{\text {vul97}}\right)$ (supplemental Fig. $1 B$, available at www.jneurosci.org as supplemental material). All trpalb cDNA derived from these mutant fish is generated by using a cryptic splice site within intron 10 that causes a frame shift (data not shown), leading to a premature stop codon (supplemental Fig. $1 B$, available at www.jneurosci.org as supplemental material). The protein encoded by this mutated gene lacks some ankyrin repeats and all transmembrane domains, and should therefore be nonfunctional.

We next used these mutants to test whether TRPAla or TRPA1b is required for the behavioral response to chemical irritants. Larvae heterozygous for mutations in trpala alone, trpa1b alone, or both trpala and trpalb responded to mustard oil to an extent similar to that of their wild-type siblings (data not shown). trpa1a homozygous mutants also exhibited a normal response to mustard oil (Fig. $3 A, D$; supplemental Fig. 5E, $F$, available at www.jneurosci.org as supplemental material). In contrast, both trpa1b homozygous mutants and trpa1a; trpa1b doubly homozygous mutants exhibited almost no response to mustard oil, indicating that only TRPA1b is essential for this response (Fig. $3 A, D$; supplemental Fig. 5E, F, available at www.jneurosci.org as supplemental material). Similarly, both trpa1b homozygous mutants and trpala; trpalb doubly homozygous mutants exhibited no responses to acrolein (supplemental Fig. 4A, available at www. jneurosci.org as supplemental material) or 4-HNE (supplemental Movie 2, available at www.jneurosci.org as supplemental material) and reduced responses to cinnamon oil and DADS (supplemental Fig. 4B,C, available at www.jneurosci.org as supplemental material). These results are consistent with our mRNA expression analysis showing that trpalb is expressed in sensory neurons that innervate the skin (Fig. $1 E, F$ ), whereas trpala expression is restricted to sensory neurons innervating visceral organs (Fig. 1C,D) that should not be activated by externally applied compounds.

\section{Zebrafish TRPA1 paralogs are not required for behavioral responses to thermal stimuli}

TRPA1 has been implicated in sensing thermal stimuli in other systems, but these results are controversial (Story et al., 2003; Viswanath et al., 2003; Bandell et al., 2004; Jordt et al., 2004; Rosenzweig et al., 2005; Bautista et al., 2006; Kwan et al., 2006; Klionsky et al., 2007; Sawada et al., 2007; Zurborg et al., 2007; Fajardo et al., 2008; Hamada et al., 2008; Kwon et al., 2008). In pilot experiments, we found that zebrafish larvae prefer temperatures between 22 and $30^{\circ} \mathrm{C}$ and that immersion in water at temperatures $>37^{\circ} \mathrm{C}$ or $<16^{\circ} \mathrm{C}$ causes robust increases in locomotor activity (data not shown). To test whether the zebrafish TRPA1 paralogs are required for behavioral responses to noxious heat and cold, we shifted larvae from their preferred temperature of $28^{\circ} \mathrm{C}$ to temperatures of noxious heat $\left(>37^{\circ} \mathrm{C}\right)$ or noxious cold $\left(<16^{\circ} \mathrm{C}\right)$. We found that trpala; trpalb doubly homozygous mutants exhibited increased locomotor activity in response to both 

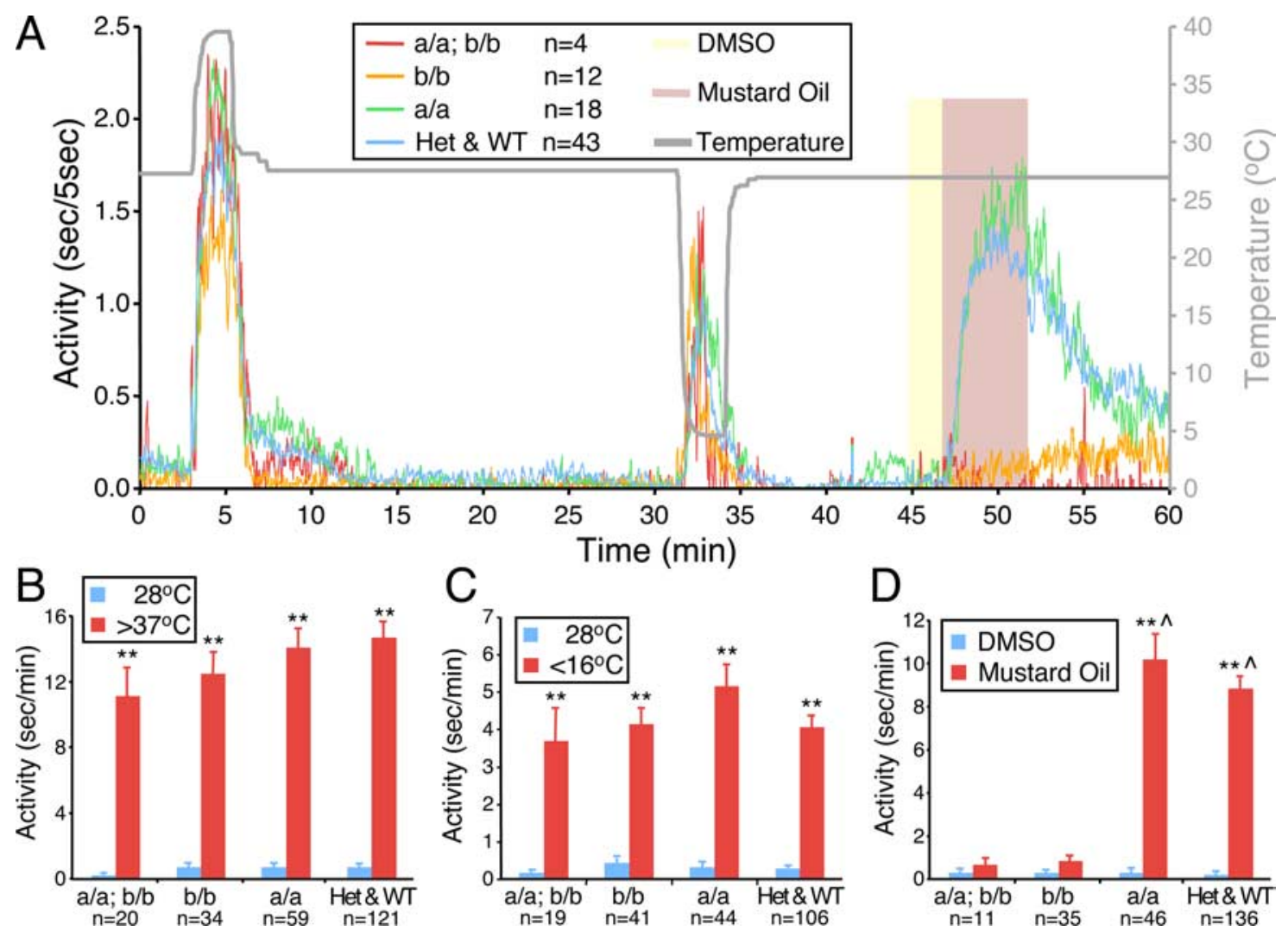

Figure 3. Zebrafish TRPA1 paralogs are required for normal behavioral responses to mustard oil but not to noxious temperatures. $A$, Each data point represents the average duration of locomotor activity every $5 \mathrm{~s}$ for the indicated number of larvae of each genotype. The gray line and right axis indicate water temperature. Yellow and red shading indicate exposure of larvae to $1 \%$ DMSO and

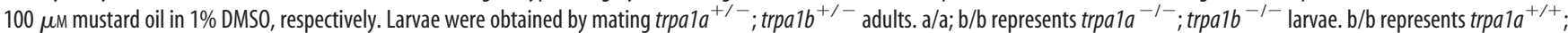

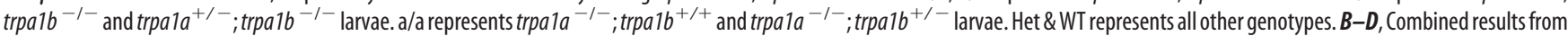
three independent experiments for each condition are shown. Each bar represents the average seconds of locomotor activity per minute \pm SEM. Blue bars represent locomotor activity during 2 min before temperature change $(\boldsymbol{B}, \boldsymbol{C})$ or during exposure to $1 \% \operatorname{DMSO}(\boldsymbol{D})$. The locomotor activity of larvae of all genotypes dramatically increased after exposure to noxious heat $\left(>37^{\circ} \mathrm{C}\right)(\boldsymbol{A}, \boldsymbol{B})$ or noxious cold $\left(<16^{\circ} \mathrm{C}\right)(\boldsymbol{A}, \mathrm{C})$. Temperatures between 4 and $16^{\circ} \mathrm{C}$ had similar stimulatory effects on locomotor activity (data not shown). DMSO alone had no effect on locomotor activity $(A, D)$. Mustard oil dramatically increased locomotor activity of larvae of all genotypes except those homozygous mutant for trpa1b or doubly homozygous mutant for trpa $1 a$ and trpa $1 b(\boldsymbol{A}, \boldsymbol{D}) .{ }^{* *} p<0.01$ for $28^{\circ} \mathrm{C}$ versus $>37^{\circ} \mathrm{C}, 28^{\circ} \mathrm{C}$ versus $<16^{\circ} \mathrm{C}$, and DMSO versus mustard oil; ${ }^{\wedge} p<0.01$ for mustard oil versus $\mathrm{b} / \mathrm{b}$ mustard oil or versus a/a; $\mathrm{b} / \mathrm{b}$ mustard oil, all by two-tailed Student's $t$ test.

noxious heat and cold that was not significantly different from the responses of their heterozygous or wild-type siblings (Fig. $3 A-C$; supplemental Fig. $5 A-D$, available at www.jneurosci.org as supplemental material).

To test for more subtle temperature-sensing defects, larvae were shifted from $28^{\circ} \mathrm{C}$ to slightly warmer or cooler temperatures. Temperature shifts from 28 to $22^{\circ} \mathrm{C}$ or from 28 to $30^{\circ} \mathrm{C}$ did not elicit behavioral responses (data not shown), whereas shifts from 28 to 20,32 , or $34^{\circ} \mathrm{C}$ induced moderate increases in locomotor activity (supplemental Fig. 6, available at www. jneurosci.org as supplemental material). In all cases, trpala; trpalb doubly homozygous mutants exhibited responses that were not significantly different from their heterozygous and wildtype siblings. Together, these experiments demonstrate that TRPA1 channels are not required for behavioral responses to thermal stimuli in zebrafish larvae.

\section{Zebrafish TRPA1 paralogs are not required for} mechanosensory function of inner ear or lateral line hair cells Knockdown of trpal expression using siRNAs in mammals or morpholino antisense oligonucleotides in zebrafish larvae suggested that TRPA1 function is required for inner ear and lateral line hair cell function in vivo (Corey et al., 2004). Subsequent analyses showed that TRPA1 knock-out mice have normal inner ear hair cell function (Bautista et al., 2006; Kwan et al., 2006).
However, it remains unclear whether TRPA1 is required for hair cell function in zebrafish. To assess the function of hair cells in the inner ear, we used extracellular microelectrodes to record microphonic potentials in response to mechanical stimulation (Sidi et al., 2003; Kappler et al., 2004). Because the sensory epithelia of the anterior and posterior maculae contain complements of hair cells oriented in opposing directions, wild-type larvae tested at $7 \mathrm{~d}$ postfertilization $(\mathrm{dpf})$ produce responses at twice the frequency of stimulation (Fig. 4A). trpala; trpalb doubly homozygous mutant larvae yielded responses indistinguishable from those of wild-type animals (Fig. $4 A$ ). In particular, the peak-to-peak magnitude of the frequency-modulated response in five double homozygous mutants, $207 \pm 27 \mu \mathrm{V}$, did not differ significantly from that of five wild-type animals, $193 \pm 65 \mu \mathrm{V}$.

We next tested the ability of inner ear and lateral line hair cells to take up the fluorophore FM1-43, which enters hair cells through functional mechanotransduction channels (Kappler et al., 2004). FM1-43 was injected into the otic vesicle to label inner ear hair cells, and whole larvae were immersed in FM1-43 to label lateral line neuromasts. In both trpala; trpalb doubly homozygous mutant and wild-type larvae, all anterior macular, lateral crista, and lateral line hair cells exhibited normal FM1-43 uptake (Fig. $4 B-E$ ). As a negative control, larvae were treated with neomycin, which ablates lateral line hair cells (Ma et al., 2008), and therefore no uptake was observed (Fig. 4D). Although there was 

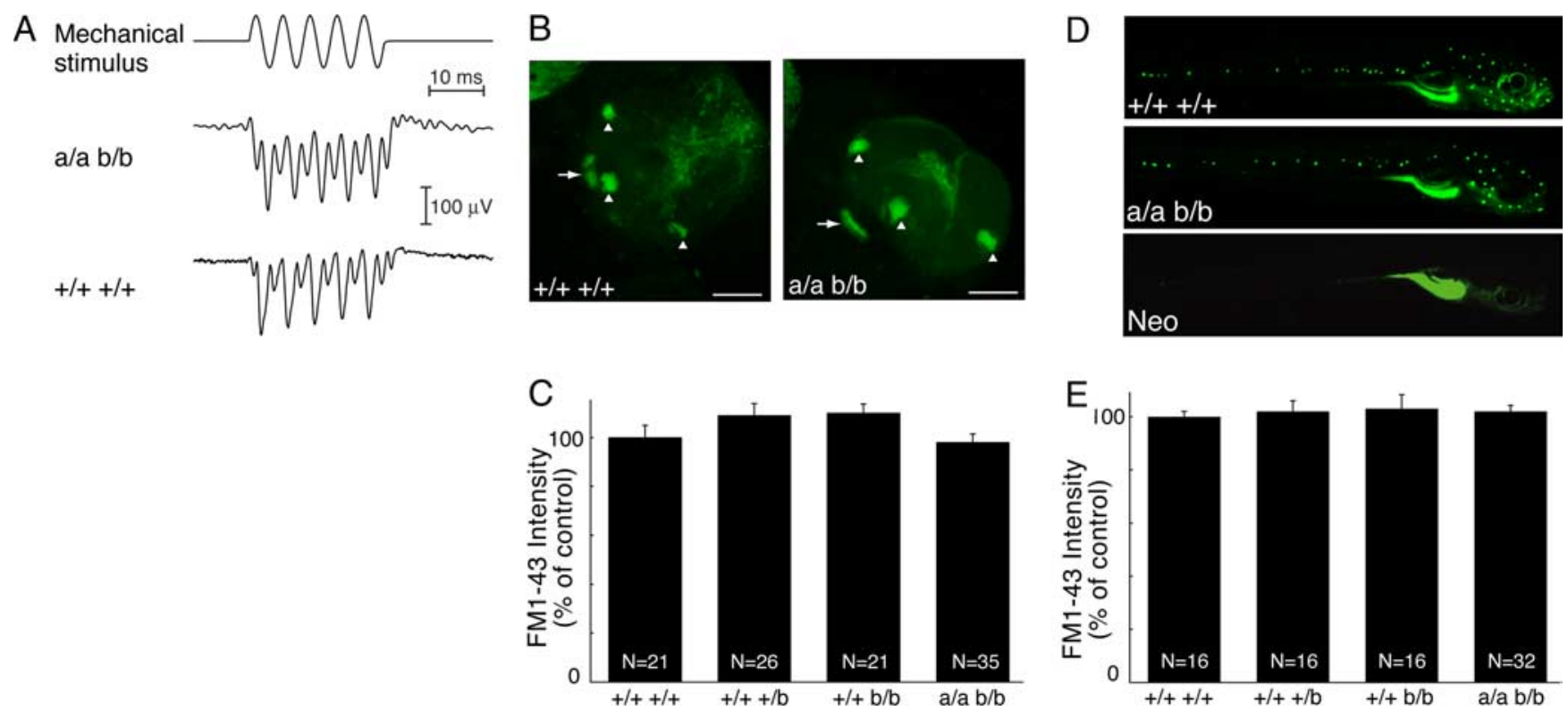

Figure 4. Zebrafish TRPA1 paralogs are not required for inner ear or neuromast mechanosensory hair cell function. $A$, A stimulus consisting of five cycles of a $200 \mathrm{~Hz}$ sinusoidal deflection of \pm 3 $\mu \mathrm{m}$ (top) excites microphonic responses in larval otocysts. Like the response of a wild-type larva (bottom), a representative microphonic potential from a trpa10 ${ }^{-I-}$; trpa1b ${ }^{-I-}$ larva (middle) displays oscillations at twice the frequency of stimulation. Each record represents the average response from 500 repetitions of the stimulus. $B$, FM1-43 labeling of otocystic hair cells of wild-type (left) and trpa1a ${ }^{-1-} ; \operatorname{trpa}_{1 b^{-1-}}$ (right) larvae at $13 \mathrm{dpf}$. Projections of 40 optical sections through each ear are shown. Arrowheads and arrows indicate cristae and anterior maculae, respectively. Scale bars, $75 \mu \mathrm{m}$. C, Relative intensity of FM1-43-labeled otocystic hair cells. N is the number of internal ear sensory patches quantitated. D, FM1-43 labeling of lateral line hair cells of wild-type (top), trpa1a ${ }^{-1-} ; \operatorname{trpa1b}^{-1-}$ (middle), and neomycin-treated wild-type (bottom) larvae at $7 \mathrm{dpf}$. $\boldsymbol{E}$, Quantitation of FM1-43 labeling intensity of lateral line hair cells. The fluorescence intensity of one posterior lateral line (L1) (Ghysen and Dambly-Chaudiere, 2004) and one anterior lateral line (MI1) (Raible and Kruse, 2000) neuromast was quantitated for each larva. $N$ is the total number of neuromasts quantitated. Error bars represent SEM.

modest variability in labeling between animals, this variability did not correlate with genotype (data not shown). We therefore conclude that the zebrafish TRPA1 paralogs are not necessary for mechanically evoked uptake of FM1-43 by hair cells.

As a final test of inner-ear function in trpal mutant larvae, we assayed behavioral responses to an acoustic stimulus. We used a mechanical solenoid to tap the 96-well plate in the video tracking system and recorded locomotor responses. As a control, we tested the response of mariner mutants, which lack acoustic vibrational sensitivity and inner ear microphonic potentials (Nicolson et al., 1998) because of a mutation in myosin VIIa (Ernest et al., 2000). Wild-type larvae exhibited brief but robust locomotor activity in response to each of three taps that were applied $30 \mathrm{~s}$ apart (supplemental Fig. 7, available at www.jneurosci.org as supplemental material). In contrast, mariner mutants did not respond to the stimuli (supplemental Fig. 7, available at www.jneurosci.org as supplemental material). We then tested the response of trpal mutants to a series of 10 taps spaced 10 min apart. trpala; trpalb doubly homozygous mutant larvae exhibited responses indistinguishable from those of their doubly heterozygous mutant siblings (Fig. 5), indicating that TRPA1 channels are not required for behavioral responses to acoustic vibrational stimuli in zebrafish larvae.

\section{Discussion}

In this study, we found that the two zebrafish TRPA1 paralogs, trpala and trpalb, are expressed in discrete patterns in larval sensory neurons. trpala is exclusively expressed in neurons in the most posterior vagal sensory ganglion, which innervate visceral organs such as the gut and intestine. In contrast, trpalb is expressed in trigeminal and Rohon-Beard sensory neurons that innervate the skin, as well as in subsets of neurons in all cranial sensory ganglia. These expression patterns suggest that TRPA1b can be activated by both internal and external stimuli, whereas TRPAla likely only detects internal stimuli.

We found that zebrafish TRPAla and TRPA1b, like mammalian TRPA1, can be activated by the pain-inducing natural products allyl isothiocyanate, cinnamaldehyde, and diallyl disulfide, by the environmental irritant acrolein, and by the endogenous compound 4-hydroxynonenal. A loss-of-function mutation in zebrafish trpalb reduced or abolished the robust increase in locomotor activity induced by these chemicals. We suggest that TRPA1a function was not necessary for behavioral responses to chemical irritants in our assay because the externally applied chemicals likely did not reach the internal organs that are innervated by trpala-expressing neurons. In contrast to these results using chemical irritants, zebrafish larvae lacking both trpala and trpa1b exhibited normal behavioral responses to thermal stimuli and had normal mechanosensory hair cell function. These findings are largely consistent with those obtained in mice lacking TRPA1, although there is some controversy surrounding the role of TRPA1 in cold sensitivity in mammals. Bautista et al. (2006) reported that TRPA1-deficient mice display normal behavioral responses to cold. In contrast, Kwan et al. (2006) reported differences in the cold sensitivity of wild-type and TRPA1-deficient mice at the behavioral level, and Fajardo et al. (2008) found that nodose ganglion neurons from TRPA1-deficient mice have reduced cold-evoked responses.

A previous study reported that knockdown of the expression of trpa $1 a$, but not of trpa1b, with morpholino antisense oligonucleotides impaired both inner ear and lateral line hair cell function in zebrafish larvae (Corey et al., 2004). In contrast, we found that trpala; trpalb doubly homozygous mutant zebrafish larvae have normal hair cell function. Similarly, knockdown of trpal expression in mouse hair cells by siRNAs inhibited hair cell func- 
tion (Corey et al., 2004), whereas hair cell function is normal in trpal mutant mice (Bautista et al., 2006; Kwan et al., 2006). Although the reasons for these discrepancies are unclear, it is well established that morpholinos can cause nonspecific phenotypes such as cell death or developmental delay (Robu et al., 2007) (D. A. Prober and A. F. Schier, unpublished data). Because the analysis of morpholino-injected fish was performed soon after hair cells would normally have become functional in zebrafish development (Corey et al., 2004), it is possible that developmental delay caused by the morpholinos led to the observed phenotypes.

Since the zebrafish TRPA1 paralogs are not required for inner ear or lateral line hair cell function, what molecules mediate mechanotransduction in these sensory cells? A potential candidate is NompC, which is required for touch sensitivity in adult Drosophila sensory bristles (Walker et al., 2000). Zebrafish have a single NompC ortholog that is expressed in hair cells (Sidi et al., 2003). Morpholinodependent knockdown of nompC expression inhibits behavioral responses to acoustic stimuli and abolishes microphonic potentials and uptake of FM1-43 in lateral line hair cells. These results indicate that NompC may play a key role in hair cell mechanotransduction in zebrafish, although a subsequent study failed to detect NompC protein at the tips of hair cell stereocilia in Xenopus (Shin et al., 2005). High-resolution analysis of NompC localization and studies using a nompC null mutant are required to confirm its potential role in hair cell mechanotransduction. Bioinformatic approaches have failed to identify a mammalian NompC ortholog (Sidi et al., 2003; Corey et al., 2004), suggesting that another protein acts as the mechanotransduction channel in mammals. Although the biophysical and pharmacological properties of the hair cell transduction channel are well established (Christensen and Corey, 2007), its molecular identity remains a mystery.

Our results raise the question of what molecules are used for thermosensation in zebrafish. Studies in mammals found that four members of the TRPV family are activated at different temperature thresholds. TRPV4 and TRPV3 are activated by warm stimuli $\left(>25^{\circ} \mathrm{C}\right.$ to $>34^{\circ} \mathrm{C}$ and $>34^{\circ} \mathrm{C}$ to $>39^{\circ} \mathrm{C}$, respectively) (Güler et al., 2002; Peier et al., 2002b; Smith et al., 2002; Watanabe et al., 2002; Xu et al., 2002), and TRPV1 and TRPV2 are activated by noxious heat $\left(>42^{\circ} \mathrm{C}\right.$ and $>52^{\circ} \mathrm{C}$, respectively) (Caterina et al., 1997, 1999). The zebrafish genome contains a single trpv4 ortholog (Mangos et al., 2007) and a single trpv1 gene that is similarly homologous to mammalian trpv1-3 (Caron et al., 2008). The generation of mutants in the zebrafish TRPV1 and TRPV4 orthologs will reveal whether these molecules function as heat sensors. TRPM8 is required for sensing cool temperatures $\left(<25^{\circ} \mathrm{C}\right)$ and is activated by the chemical menthol in mammals (McKemy et al., 2002; Peier et al., 2002a; Bautista et al., 2007; Colburn et al., 2007; Dhaka et al., 2007) and in chicken (Chuang et al., 2004). The zebrafish genome contains orthologs of several members of the trpm gene family; however, none of these genes is most closely related to trpm8 (Saito and Shingai, 2006) (D. A. Prober and A. F. Schier, unpublished data), and zebrafish larvae do not exhibit a behavioral response to menthol (Caron et al., 2008). We therefore suggest that zebrafish lack a $\operatorname{trp} m 8$ ortholog, and that other genes are used by zebrafish to sense cold temperatures. In fact, mice lacking TRPM8 still retain some sensitivity to noxious cold $\left(<15^{\circ} \mathrm{C}\right)$ (Bautista et al., 2007; Colburn et al., 2007; Dhaka et al., 2007), suggesting that as yet unidentified molecules contribute to cold sensing in mammals as well. Genetic and pharmacologic screens in zebrafish will facilitate discovery of the genes required to sense these stimuli.

Finally, our study establishes the zebrafish as a powerful system for the study of nociceptive behaviors in vertebrates. Our high-throughput, quantitative locomotor activity assay allows the analysis of hundreds of larvae simultaneously. This system is well suited for large-scale behavioral screens to identify novel genes and drugs that regulate behavioral responses to a range of thermal, chemical, and mechanical stimuli.

\section{References}

Al-Anzi B, Tracey WD Jr, Benzer S (2006) Response of Drosophila to wasabi is mediated by painless, the fly homolog of mammalian TRPA1/ ANKTM1. Curr Biol 16:1034-1040.

Bandell M, Story GM, Hwang SW, Viswanath V, Eid SR, Petrus MJ, Earley TJ, 
Patapoutian A (2004) Noxious cold ion channel TRPA1 is activated by pungent compounds and bradykinin. Neuron 41:849-857.

Bandell M, Macpherson LJ, Patapoutian A (2007) From chills to chilis: mechanisms for thermosensation and chemesthesis via thermoTRPs. Curr Opin Neurobiol 17:490-497.

Barth KA, Miklosi A, Watkins J, Bianco IH, Wilson SW, Andrew RJ (2005) fsi zebrafish show concordant reversal of laterality of viscera, neuroanatomy, and a subset of behavioral responses. Curr Biol 15:844-850.

Bautista DM, Movahed P, Hinman A, Axelsson HE, Sterner O, Högestätt ED, Julius D, Jordt SE, Zygmunt PM (2005) Pungent products from garlic activate the sensory ion channel TRPA1. Proc Natl Acad Sci U S A 102:12248-12252.

Bautista DM, Jordt SE, Nikai T, Tsuruda PR, Read AJ, Poblete J, Yamoah EN, Basbaum AI, Julius D (2006) TRPA1 mediates the inflammatory actions of environmental irritants and proalgesic agents. Cell 124:1269-1282.

Bautista DM, Siemens J, Glazer JM, Tsuruda PR, Basbaum AI, Stucky CL, Jordt SE, Julius D (2007) The menthol receptor TRPM8 is the principal detector of environmental cold. Nature 448:204-208.

Bhatt DH, McLean DL, Hale ME, Fetcho JR (2007) Grading movement strength by changes in firing intensity versus recruitment of spinal interneurons. Neuron 53:91-102.

Burgess HA, Granato M (2007) Sensorimotor gating in larval zebrafish. J Neurosci 27:4984-4994.

Caron SJ, Prober D, Choy M, Schier AF (2008) In vivo birthdating by BAPTISM revelas that trigeminal sensory neuron diversity depends on early neurogenesis. Development 135:3259-3269.

Caterina MJ (2007) Transient receptor potential ion channels as participants in thermosensation and thermoregulation. Am J Physiol Regul Integr Comp Physiol 292:R64-R76.

Caterina MJ, Schumacher MA, Tominaga M, Rosen TA, Levine JD, Julius D (1997) The capsaicin receptor: a heat-activated ion channel in the pain pathway. Nature 389:816-824.

Caterina MJ, Rosen TA, Tominaga M, Brake AJ, Julius D (1999) A capsaicin-receptor homologue with a high threshold for noxious heat. Nature 398:436-441.

Christensen AP, Corey DP (2007) TRP channels in mechanosensation: direct or indirect activation? Nat Rev Neurosci 8:510-521.

Chuang HH, Neuhausser WM, Julius D (2004) The super-cooling agent icilin reveals a mechanism of coincidence detection by a temperaturesensitive TRP channel. Neuron 43:859-869.

Colburn RW, Lubin ML, Stone DJ Jr, Wang Y, Lawrence D, D’Andrea MR, Brandt MR, Liu Y, Flores CM, Qin N (2007) Attenuated cold sensitivity in TRPM8 null mice. Neuron 54:379-386.

Corey DP, García-Añoveros J, Holt JR, Kwan KY, Lin SY, Vollrath MA, Amalfitano A, Cheung EL, Derfler BH, Duggan A, Géléoc GS, Gray PA, Hoffman MP, Rehm HL, Tamasauskas D, Zhang DS (2004) TRPA1 is a candidate for the mechanosensitive transduction channel of vertebrate hair cells. Nature 432:723-730.

Dhaka A, Murray AN, Mathur J, Earley TJ, Petrus MJ, Patapoutian A (2007) TRPM8 is required for cold sensation in mice. Neuron 54:371-378.

Doerner JF, Gisselmann G, Hatt H, Wetzel CH (2007) Transient receptor potential channel A1 is directly gated by calcium ions. J Biol Chem 282:13180-13189.

Driever W, Solnica-Krezel L, Schier AF, Neuhauss SC, Malicki J, Stemple DL, Stainier DY, Zwartkruis F, Abdelilah S, Rangini Z, Belak J, Boggs C (1996) A genetic screen for mutations affecting embryogenesis in zebrafish. Development 123:37-46.

Ernest S, Rauch GJ, Haffter P, Geisler R, Petit C, Nicolson T (2000) Mariner is defective in myosin VIIA: a zebrafish model for human hereditary deafness. Hum Mol Genet 9:2189-2196.

Fajardo O, Meseguer V, Belmonte C, Viana F (2008) TRPA1 channels mediate cold temperature sensing in mammalian vagal sensory neurons: pharmacological and genetic evidence. J Neurosci 28:7863-7875.

Ghysen A, Dambly-Chaudière C (2004) Development of the zebrafish lateral line. Curr Opin Neurobiol 14:67-73.

Granato M, van Eeden FJ, Schach U, Trowe T, Brand M, Furutani-Seiki M, Haffter P, Hammerschmidt M, Heisenberg CP, Jiang YJ, Kane DA, Kelsh RN, Mullins MC, Odenthal J, Nüsslein-Volhard C (1996) Genes controlling and mediating locomotion behavior of the zebrafish embryo and larva. Development 123:399-413.

Güler AD, Lee H, Iida T, Shimizu I, Tominaga M, Caterina M (2002) Heatevoked activation of the ion channel, TRPV4. J Neurosci 22:6408-6414.
Haffter P, Granato M, Brand M, Mullins MC, Hammerschmidt M, Kane DA, Odenthal J, van Eeden FJ, Jiang YJ, Heisenberg CP, Kelsh RN, FurutaniSeiki M, Vogelsang E, Beuchle D, Schach U, Fabian C, Nüsslein-Volhard C (1996) The identification of genes with unique and essential functions in the development of the zebrafish, Danio rerio. Development 123:1-36.

Hamada FN, Rosenzweig M, Kang K, Pulver SR, Ghezzi A, Jegla TJ, Garrity PA (2008) An internal thermal sensor controlling temperature preference in Drosophila. Nature 454:217-220.

Isken O, Maquat LE (2007) Quality control of eukaryotic mRNA: safeguarding cells from abnormal mRNA function. Genes Dev 21:1833-1856.

Jordt SE, Bautista DM, Chuang HH, McKemy DD, Zygmunt PM, Högestätt ED, Meng ID, Julius D (2004) Mustard oils and cannabinoids excite sensory nerve fibres through the TRP channel ANKTM1. Nature 427:260-265.

Kappler JA, Starr CJ, Chan DK, Kollmar R, Hudspeth AJ (2004) A nonsense mutation in the gene encoding a zebrafish myosin VI isoform causes defects in hair-cell mechanotransduction. Proc Natl Acad Sci U S A 101:13056-13061.

Kindt KS, Viswanath V, Macpherson L, Quast K, Hu H, Patapoutian A, Schafer WR (2007) Caenorhabditis elegans TRPA-1 functions in mechanosensation. Nat Neurosci 10:568-577.

Klionsky L, Tamir R, Gao B, Wang W, Immke DC, Nishimura N, Gavva NR (2007) Species-specific pharmacology of trichloro(sulfanyl)ethyl benzamides as transient receptor potential ankyrin 1 (TRPA1) antagonists. Mol Pain 3:39.

Kwan KY, Allchorne AJ, Vollrath MA, Christensen AP, Zhang DS, Woolf CJ, Corey DP (2006) TRPA1 contributes to cold, mechanical, and chemical nociception but is not essential for hair-cell transduction. Neuron 50:277-289.

Kwon Y, Shim HS, Wang X, Montell C (2008) Control of thermotactic behavior via coupling of a TRP channel to a phospholipase C signaling cascade. Nat Neurosci 11:871-873.

Ma EY, Rubel EW, Raible DW (2008) Notch signaling regulates the extent of hair cell regeneration in the zebrafish lateral line. J Neurosci 28:2261-2273.

Macpherson LJ, Geierstanger BH, Viswanath V, Bandell M, Eid SR, Hwang S, Patapoutian A (2005) The pungency of garlic: activation of TRPA1 and TRPV1 in response to allicin. Curr Biol 15:929-934.

Macpherson LJ, Xiao B, Kwan KY, Petrus MJ, Dubin AE, Hwang S, Cravatt B, Corey DP, Patapoutian A (2007) An ion channel essential for sensing chemical damage. J Neurosci 27:11412-11415.

Mangos S, Liu Y, Drummond IA (2007) Dynamic expression of the osmosensory channel trpv4 in multiple developing organs in zebrafish. Gene Expr Patterns 7:480-484.

McKemy DD, Neuhausser WM, Julius D (2002) Identification of a cold receptor reveals a general role for TRP channels in thermosensation. Nature 416:52-58.

McLean DL, Fetcho JR (2008) Using imaging and genetics in zebrafish to study developing spinal circuits in vivo. Dev Neurobiol 68:817-834.

McLean DL, Fan J, Higashijima S, Hale ME, Fetcho JR (2007) A topographic map of recruitment in spinal cord. Nature 446:71-75.

McNamara CR, Mandel-Brehm J, Bautista DM, Siemens J, Deranian KL, Zhao M, Hayward NJ, Chong JA, Julius D, Moran MM, Fanger CM (2007) TRPA1 mediates formalin-induced pain. Proc Natl Acad Sci U S A 104:13525-13530.

Metcalfe WK, Myers PZ, Trevarrow B, Bass MB, Kimmel CB (1990) Primary neurons that express the L2/HNK-1 carbohydrate during early development in the zebrafish. Development 110:491-504.

Montell C, Caterina MJ (2007) Thermoregulation: channels that are cool to the core. Curr Biol 17:R885-887.

Muto A, Orger MB, Wehman AM, Smear MC, Kay JN, Page-McCaw PS, Gahtan E, Xiao T, Nevin LM, Gosse NJ, Staub W, Finger-Baier K, Baier H (2005) Forward genetic analysis of visual behavior in zebrafish. PLoS Genet 1:e66.

Nechiporuk A, Linbo T, Poss KD, Raible DW (2007) Specification of epibranchial placodes in zebrafish. Development 134:611-623.

Nicolson T, Rüsch A, Friedrich RW, Granato M, Ruppersberg JP, NüssleinVolhard C (1998) Genetic analysis of vertebrate sensory hair cell mechanosensation: the zebrafish circler mutants. Neuron 20:271-283.

North TE, Goessling W, Walkley CR, Lengerke C, Kopani KR, Lord AM, Weber GJ, Bowman TV, Jang IH, Grosser T, Fitzgerald GA, Daley GQ, 
Orkin SH, Zon LI (2007) Prostaglandin E2 regulates vertebrate haematopoietic stem cell homeostasis. Nature 447:1007-1011.

Olsson C, Holmberg A, Holmgren S (2008) Development of enteric and vagal innervation of the zebrafish (Danio rerio) gut. J Comp Neurol 508:756-770.

Orger MB, Kampff AR, Severi KE, Bollmann JH, Engert F (2008) Control of visually guided behavior by distinct populations of spinal projection neurons. Nat Neurosci 11:327-333.

Peier AM, Moqrich A, Hergarden AC, Reeve AJ, Andersson DA, Story GM, Earley TJ, Dragoni I, McIntyre P, Bevan S, Patapoutian A (2002a) A TRP channel that senses cold stimuli and menthol. Cell 108:705-715.

Peier AM, Reeve AJ, Andersson DA, Moqrich A, Earley TJ, Hergarden AC, Story GM, Colley S, Hogenesch JB, McIntyre P, Bevan S, Patapoutian A (2002b) A heat-sensitive TRP channel expressed in keratinocytes. Science 296:2046-2049.

Peterson RT, Link BA, Dowling JE, Schreiber SL (2000) Small molecule developmental screens reveal the logic and timing of vertebrate development. Proc Natl Acad Sci U S A 97:12965-12969.

Postlethwait JH (2007) The zebrafish genome in context: ohnologs gone missing. J Exp Zoolog B Mol Dev Evol 308:563-577.

Prober DA, Rihel J, Onah AA, Sung RJ, Schier AF (2006) Hypocretin/orexin overexpression induces an insomnia-like phenotype in zebrafish. J Neurosci 26:13400-13410.

Raible DW, Kruse GJ (2000) Organization of the lateral line system in embryonic zebrafish. J Comp Neurol 421:189-198.

Raible DW, Ungos JM (2006) Specification of sensory neuron cell fate from the neural crest. Adv Exp Med Biol 589:170-180.

Robu ME, Larson JD, Nasevicius A, Beiraghi S, Brenner C, Farber SA, Ekker SC (2007) p53 activation by knockdown technologies. PLoS Genet 3:e78.

Rosenzweig M, Brennan KM, Tayler TD, Phelps PO, Patapoutian A, Garrity PA (2005) The Drosophila ortholog of vertebrate TRPA1 regulates thermotaxis. Genes Dev 19:419-424.

Sachidanandan C, Yeh JR, Peterson QP, Peterson RT (2008) Identification of a novel retinoid by small molecule screening with zebrafish embryos. PLoS ONE 3:e1947.

Sagasti A, Guido MR, Raible DW, Schier AF (2005) Repulsive interactions shape the morphologies and functional arrangement of zebrafish peripheral sensory arbors. Curr Biol 15:804-814.

Saito S, Shingai R (2006) Evolution of thermoTRP ion channel homologs in vertebrates. Physiol Genomics 27:219-230.

Santos F, MacDonald G, Rubel EW, Raible DW (2006) Lateral line hair cell maturation is a determinant of aminoglycoside susceptibility in zebrafish (Danio rerio). Hear Res 213:25-33.
Sawada Y, Hosokawa H, Hori A, Matsumura K, Kobayashi S (2007) Cold sensitivity of recombinant TRPA1 channels. Brain Res 1160:39-46.

Shin JB, Adams D, Paukert M, Siba M, Sidi S, Levin M, Gillespie PG, Gründer S (2005) Xenopus TRPN1 (NOMPC) localizes to microtubule-based cilia in epithelial cells, including inner-ear hair cells. Proc Natl Acad Sci U S A 102:12572-12577.

Sidi S, Friedrich RW, Nicolson T (2003) NompC TRP channel required for vertebrate sensory hair cell mechanotransduction. Science 301:96-99.

Smith GD, Gunthorpe MJ, Kelsell RE, Hayes PD, Reilly P, Facer P, Wright JE, Jerman JC, Walhin JP, Ooi L, Egerton J, Charles KJ, Smart D, Randall AD, Anand P, Davis JB (2002) TRPV3 is a temperature-sensitive vanilloid receptor-like protein. Nature 418:186-190.

Starr CJ, Kappler JA, Chan DK, Kollmar R, Hudspeth AJ (2004) Mutation of the zebrafish choroideremia gene encoding Rab escort protein 1 devastates hair cells. Proc Natl Acad Sci U S A 101:2572-2577.

Story GM, Peier AM, Reeve AJ, Eid SR, Mosbacher J, Hricik TR, Earley TJ, Hergarden AC, Andersson DA, Hwang SW, McIntyre P, Jegla T, Bevan S, Patapoutian A (2003) ANKTM1, a TRP-like channel expressed in nociceptive neurons, is activated by cold temperatures. Cell 112:819-829.

Trevisani M, Siemens J, Materazzi S, Bautista DM, Nassini R, Campi B, Imamachi N, Andrè E, Patacchini R, Cottrell GS, Gatti R, Basbaum AI, Bunnett NW, Julius D, Geppetti P (2007) 4-Hydroxynonenal, an endogenous aldehyde, causes pain and neurogenic inflammation through activation of the irritant receptor TRPA1. Proc Natl Acad Sci U S A 104:13519-13524.

Viswanath V, Story GM, Peier AM, Petrus MJ, Lee VM, Hwang SW, Patapoutian A, Jegla T (2003) Opposite thermosensor in fruitfly and mouse. Nature 423:822-823.

Walker RG, Willingham AT, Zuker CS (2000) A Drosophila mechanosensory transduction channel. Science 287:2229-2234.

Watanabe H, Vriens J, Suh SH, Benham CD, Droogmans G, Nilius B (2002) Heat-evoked activation of TRPV4 channels in a HEK293 cell expression system and in native mouse aorta endothelial cells. J Biol Chem 277:47044-47051.

Wienholds E, Schulte-Merker S, Walderich B, Plasterk RH (2002) Targetselected inactivation of the zebrafish rag1 gene. Science 297:99-102.

Xu H, Ramsey IS, Kotecha SA, Moran MM, Chong JA, Lawson D, Ge P, Lilly J, Silos-Santiago I, Xie Y, DiStefano PS, Curtis R, Clapham DE (2002) TRPV3 is a calcium-permeable temperature-sensitive cation channel. Nature 418:181-186.

Zurborg S, Yurgionas B, Jira JA, Caspani O, Heppenstall PA (2007) Direct activation of the ion channel TRPA1 by Ca2 +. Nat Neurosci 10:277-279. 